\title{
As fotografias de "anjos" no Brasil do século XIX
}

Luiz Lima Vailati ${ }^{1}$

RESUMO: $\bigcirc$ presente artigo examina fotografias de crianças mortas produzidas em São Paulo no século XIX, de modo a pensar acerca da sensibilidade da época em relação à morte, bem como algumas transformações operadas nesse âmbito. A estratégia de análise privilegiará a identificação, nesse material, de elementos constitutivos das práticas e representações relacionadas à criança morta, cujas origens são bem anteriores à prática de registro fotográfico dos "anjos" e, na mesma medida, daqueles elementos que estão associados às mudanças que nesse universo tiveram lugar na segunda metade do século XIX e que, como cremos, acompanharam e fomentaram não só o advento mas também a extinção desse costume.

PALAVRAS-CHAVE: São Paulo. Representação da morte. Representação da criança. Fołografia de "Anjos". História da Infância. Objetos funerários.

ABSTRACT: This paper examines the photographs of dead children taken in São Paulo in the $19^{\text {th }}$ century, as a means to understand the sensibilities in relation to death at the time as well as certain changes that occurred in this domain. The analytical strategy adopted by the author focuses on the identification, in the photographic material, of the elements that constituted the practices and representations relating to deceased children, the origins of which are far older than the practice of photographing "angels". Likewise, he looks into the elements associated with the changes that took place in this sphere during the second half of the $19^{\text {th }}$ century, which he believes accompanied and fostered not only the advent but also the extinction of this custom.

KEYWORDS: São Paulo. Death Representation. Children Representation. Photographing "angels". History of childhood. Funerary objects.

Os dados apresentados no presente artigo fazem parte da investigação realizada em nossa tese de doutoramento², que discorreu acerca das práticas e representações em torno da criança morta ao longo do século XIX, no Rio de Janeiro e São Paulo, e das mudanças que ocorreram nesse âmbito. Nossa
1. Doutor em História Social pela Faculdade de Filosofia Letras e Ciências Humanas da Universidade de São Paulo. Docente dos cursos de graduação e pós graduação da Fundação Armando Álvares Penteado. E-mail: <llvailati@uol.com.br>.

2. VAILATI, 2005 
3."Fotografias de pessoas mortas, inclusive de crianças, não eram raras nos álbuns familiares Apresentavam-se, geralmente, em formato carte de visite, trazendo algumas inscrições aludindo, no verso da imagem, à morte do ente querido" (MAUAD, 1999, p. 137 191). Entre outros lugares, sabe-se também sobre os costume de se fotografarem parentes mortos no Peru, no século XIX, como nos informa Keith McElroy (1987, p. 279).

4. "Photography was introduced to Peru in 1842 and since few families had previously been able to afford handmade like nesses of their beloved ones, there was a backlog of portraits to be made. Those who died in this early period were frequently photographed for the first time during the preparations for the funeral service and this established a precedent which was followed throughout the remain der of the century" (Idem, ibidem). intenção, nas linhas que se seguem, é analisar uma amostragem das fotografias de crianças mortas que fazem parte do acervo iconográfico do Museu Paulista da USP, produzidas nas décadas de 1860 e 1880 na cidade de São Paulo. Analisaremos alguns elementos constantes desse corpus, os quais, como demonstraremos, testemunham permanências e mudanças no conjunto das atitudes em relação à morte na infância. Tendo em vista o universo de testemunhos que nos informam a respeito do objeto pesquisado, essa documentação se revela de enorme valor. Há de considerar-se, primeiramente, que grande parte das fontes (como os livros de registros de óbito e os relatos dos viajantes que por aqui passaram no decorrer do século XIX) de que comumente nos utilizamos para a reconstituição do objeto em questão, a partir do último quartel do XIX passam a calar-se acerca desse assunto, pelos mais variados motivos. Disso resulta que, além do fato de esse corpus (junto com algumas raras ilustrações feitas por artistas estrangeiros) constituir registro imagético das práticas e cultura material funerária das quais a reconstrução é, em grande parte, feita por meio de fontes escritas -, cabe também ao registro fotográfico ser um dos poucos (se não o único) testemunhos da manutenção, até o início do século XIX, de uma série de comportamentos tradicionalmente relacionados ao evento. É esse mesmo motivo que, por outro lado, torna a fotografia um recurso privilegiado (como é o caso da produção escultórica cemiterial) também para a observação de mudanças que ocorreram nesse âmbito quando passa a vigorar o silêncio de outras fontes.

acervo fotográfico relativo ao século XIX do Museu Paulista da USP dá-nos notícia de um uso do registro fotográfico que, comum já nos primeiros anos de sua difusão, hoje não é mais encontrado, sobretudo nas culturas mais urbanizadas: dele fazem parte fotografias de parentes mortos, encomendadas pelas famílias paulistas da época. Nesse caso, restringem-se exclusivamente a crianças e, mais raramente, a jovens mulheres. Com efeito, sobre o costume de se fotografar os membros mortos da família antes destes serem enterrados, Ana Maria Mauad ${ }^{3}$ observa que tais imagens têm notável presença nos álbuns de família da elite carioca durante o Império, fato que vale especialmente para as crianças. Num contexto de crescente valorização dos sentimentos familiares, no qual a fotografia é suporte privilegiado dessa manifestação, a explicação mais imediata para esse estado de coisas está no fato de ser esta a derradeira e única ocasião para deixar registrada a imagem do membro que acabara de morrer, conforme argumenta Keith McEroy para o Peru dos oitocentos ${ }^{4}$, situação tornada comum pela freqüência da morte prematura então. Como os possíveis significados dessa explicação estão relacionados a uma atitude mais recente em relação à morte menina para o período em questão, deixaremos para falar deles mais adiante.

De qualquer modo, a constatação de uma certa identidade entre crianças e jovens mulheres, revelada pela preferência ou mesmo exclusividade como objeto das fotografias mortuárias, dá indícios de sentidos que, na nossa visão, estão ligados a uma disposição mais antiga face à morte infantil e que são igualmente importantes para a explicação desse costume. É desses significados que irei me ocupar agora. 
Um deles, diz respeito, basicamente, à grande importância que era dada à morte infantil na época em estudo. Este fato, com efeito, é confirmado por alguns testemunhos referentes a todo o século XIX no Brasil, nos quais se observa um zelo significativo em proporcionar à criança que acabara de morrer uma série de procedimentos julgados indispensáveis, preocupação que atinge, por sinal, até aqueles que, devido a suas carências materiais, não deixam de surpreender ao demonstrarem tal desassossego. Era bastante freqüente, por exemplo, o hábito de depositarem-se os pequenos defuntos na roda de expostos (instrumento destinado ao recolhimento de crianças abandonadas nos séculos XVIII e XIX) da Santa Casa de Misericórdia da cidade de Salvador, para a instituição assegurar-thes que fossem devidamente enterrados ${ }^{5}$. Essa constatação é reforçada pela observação de Jean-Baptiste Debret a respeito da Corte, segundo a qual seus habitantes comumente empregavam parte considerável de seu parco pecúlio na tentativa de garantir para seus pequeninos um enterro que estivesse em conformidade com o que se esperava desse tipo de evento ${ }^{6}$. Entre os mais abastados ou não, tal era o dispêndio material e simbólico investido nessas cerimônias, que não poucas vezes ele perturbava outros viajantes que por aqui passaram no correr do século XIX como o pastor Daniel Kidder, que lembrava dos funerais de crianças como "uma procissão triunfal" ou o francês Dabadie, para o qual esses the pareceram mais apropriados para príncipes ou senadores'.

Como ficou claro no decorrer da investigação levada a cabo no doutoramento, a enorme importância dada aos funerais de criança decorriam de uma crença não só na positividade da morte infantil - morrer criança era garantia de salvação - como também nos poderes de intercessão das crianças mortas junto às autoridades celestes em favor dos seus ${ }^{8}$. É também nesse sentido que é possível ler a grande freqüência de imagens de crianças mortas no conjunto de retratos de crianças constantes do acervo do Museu. $\bigcirc$ fato de ser o seu funeral uma das principais ou a única oportunidade em que a criança é fotografada, permite pensar, entre outras coisas, ser este um sinal acerca da importância desses eventos para a manifestação do apreço pela criança. Essa constatação fica bastante reforçada pelo fato de essas crianças, na maior parte dos casos aqui analisados (Figuras 1 a 7), terem sido fotografadas logo após saírem da toalete mortuária, com todo o aparato com que então se apresentavam para os rituais fúnebres. Isso demonstra que não há qualquer preocupação com o fato de a memória da criança propiciada pelo registro fotográfico estar associada à sua morte, uma vez que todos os elementos indicativos disso estão deliberadamente visíveis - em suma, não há qualquer tentativa de esconder que o retratado está morto. É possível, então, supor que são mesmo tais sinais que tornam, aos olhos da sociedade estudada, esta ocasião a que melhor se apresenta para oferecer a imagem que deveria durar para sempre. A fotografia permitiria, assim, fixar a visão dos seus pequenos defuntos esmeradamente preparados, obrigação a que os pais não deviam furtar-se e cujo bom cumprimento, segundo vimos, parecia ser motivo de orgulho.

É nesse sentido que as fotografias de crianças mortas nos permitem entrever a continuidade, sob um novo suporte, de uma outra característica
5. Segundo Renato Pinto Venâncio, para a roda de expostos de Salvador "entre 1790 e 1796 , foram enviados 51 expostos mortos, ou seja, para $8 \%$ dos abandonados daqueles anos a Roda serviu de cemitério gratuito". No caso desta mesma prática no Rio de Janeiro, em especial na segunda metade do XIX,Venâncio observa que "a Roda serviu para perpetuar a antiqüíssima tradição de manter os vivos e os mortos o mais próximo possível, possibilitando que as mulheres pobres garantissem o enterro cristão dos filhos, o que uma vez mais sugere interpretarmos a linguagem do abandono como um código cifrado do amor materno" (VENÂNCIO, 1997). As passagens citadas estão, respectivamente, nas p. 206 e 213.

6. Explicando suas pranchas sobre enterros de "negrinhos", Debret lembra que "A negra livre remediada, sempre membro de uma irmandade religiosa, não hesita em realizar essa despesa que considera um dever" (DEBRET, 1989, p. 174)

7.Cf.Daniel Parish Kidder (1980, p. 158); e F. Dabadie (1858,p. 7): "Faites place à l'interminable suite de voitures de deuil qui se dirige vers le cimetière. Au luxe déployé, vouz pensez avoir sous les yeux le convoi d'un prince ou tout au moins d'un sénateur.Il n'en est rien cependent: le mort qu'on fête ainsi est un bambin de modeste origine".

8. Cf. Luiz Lima Vailati (2005, p. 168). 


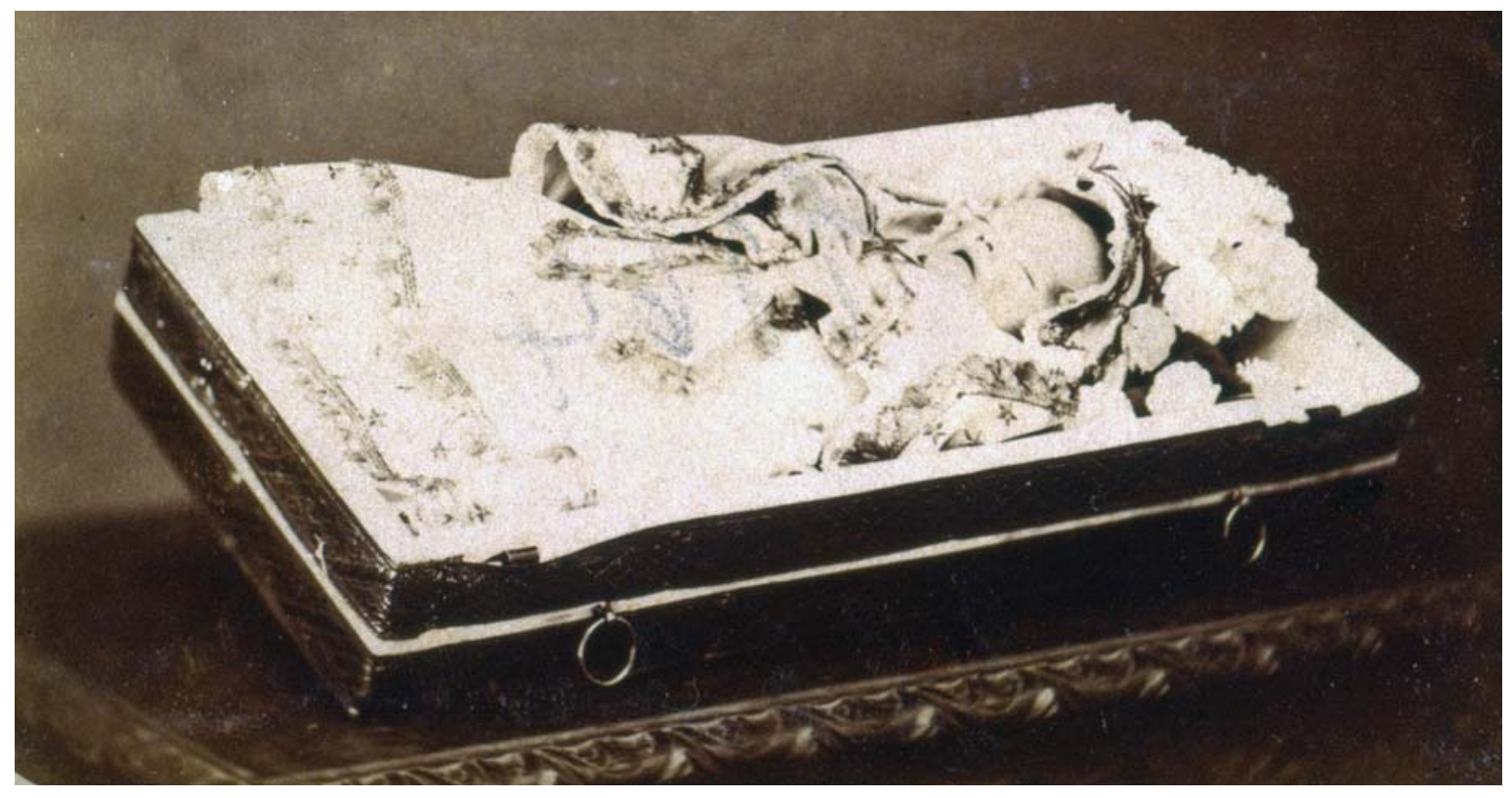

Figura 1 - Sem título. 1870. Fotografia de Militão Augusto de Azevedo. Acervo do Museu Paulista da Universidade de São Paulo.

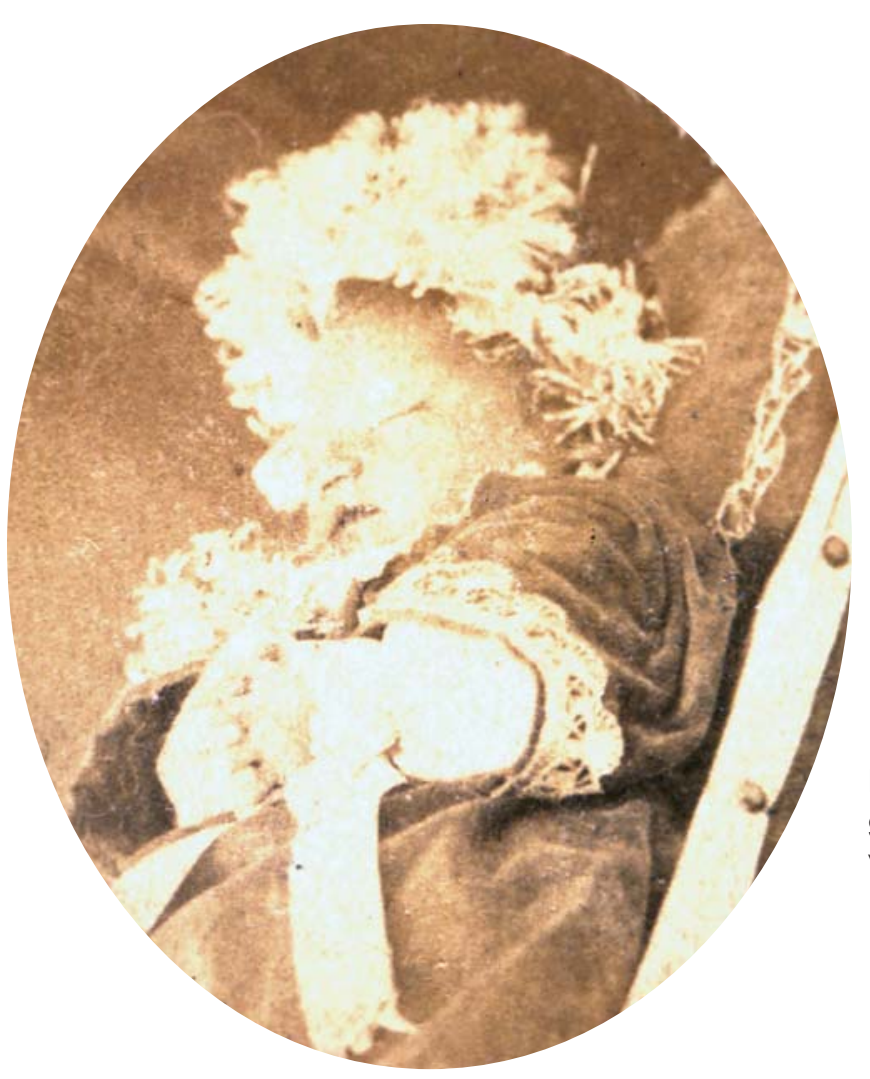

Figura 2 - Sem título. 1871. Fotografia de Militão Augusto de Azevedo. Acervo do Museu Paulista da Universidade de São Paulo. 




Figura 3 - Sem título. 1877. Fotografia de Militão Augusto de Azevedo. Acervo do Museu Paulista da Universidade de São Paulo.

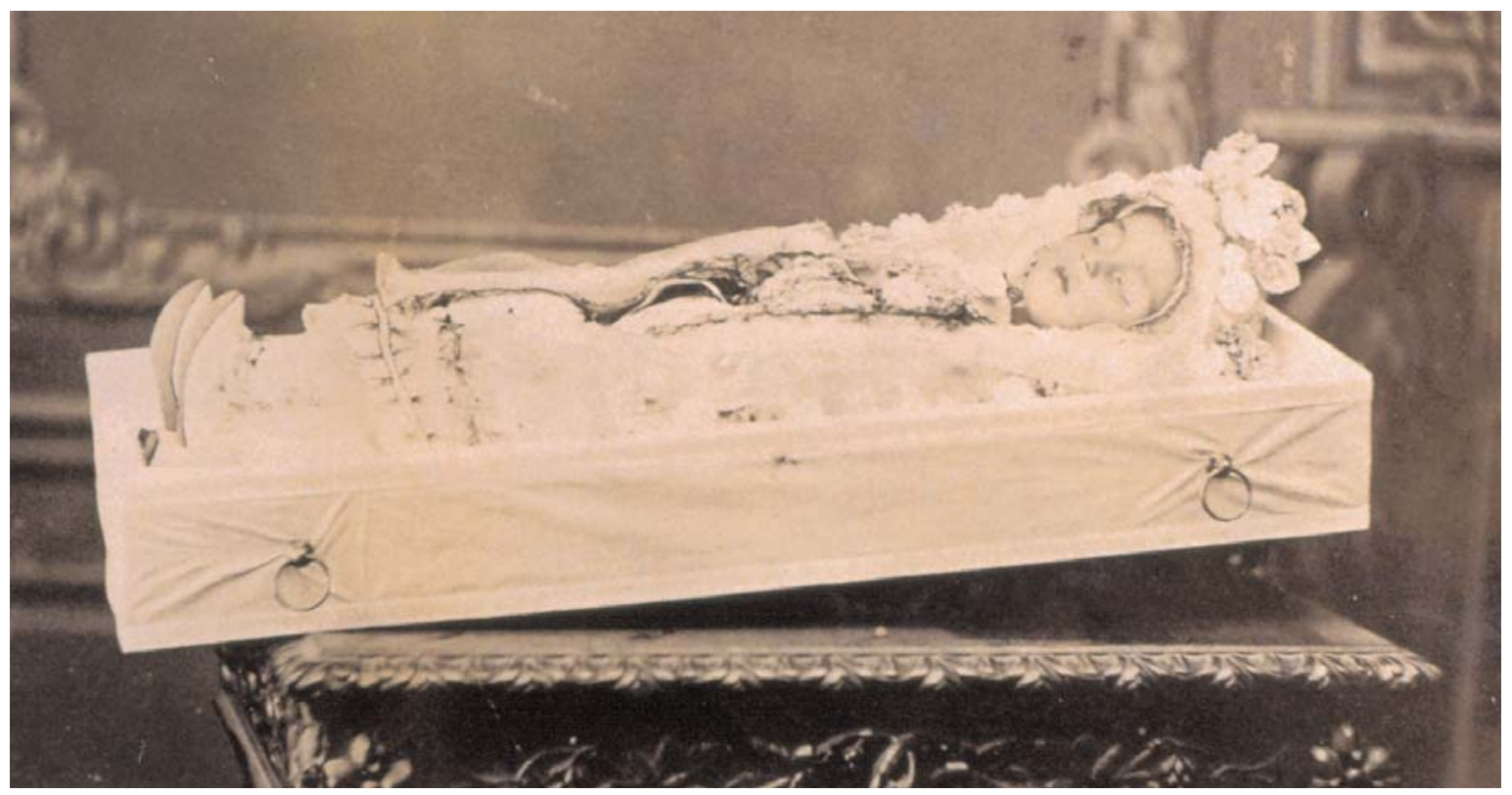

Figura 4 - Sem título. 1865. Fotografia de Militão Augusto de Azevedo. Acervo do Museu Paulista da Universidade de São Paulo. 


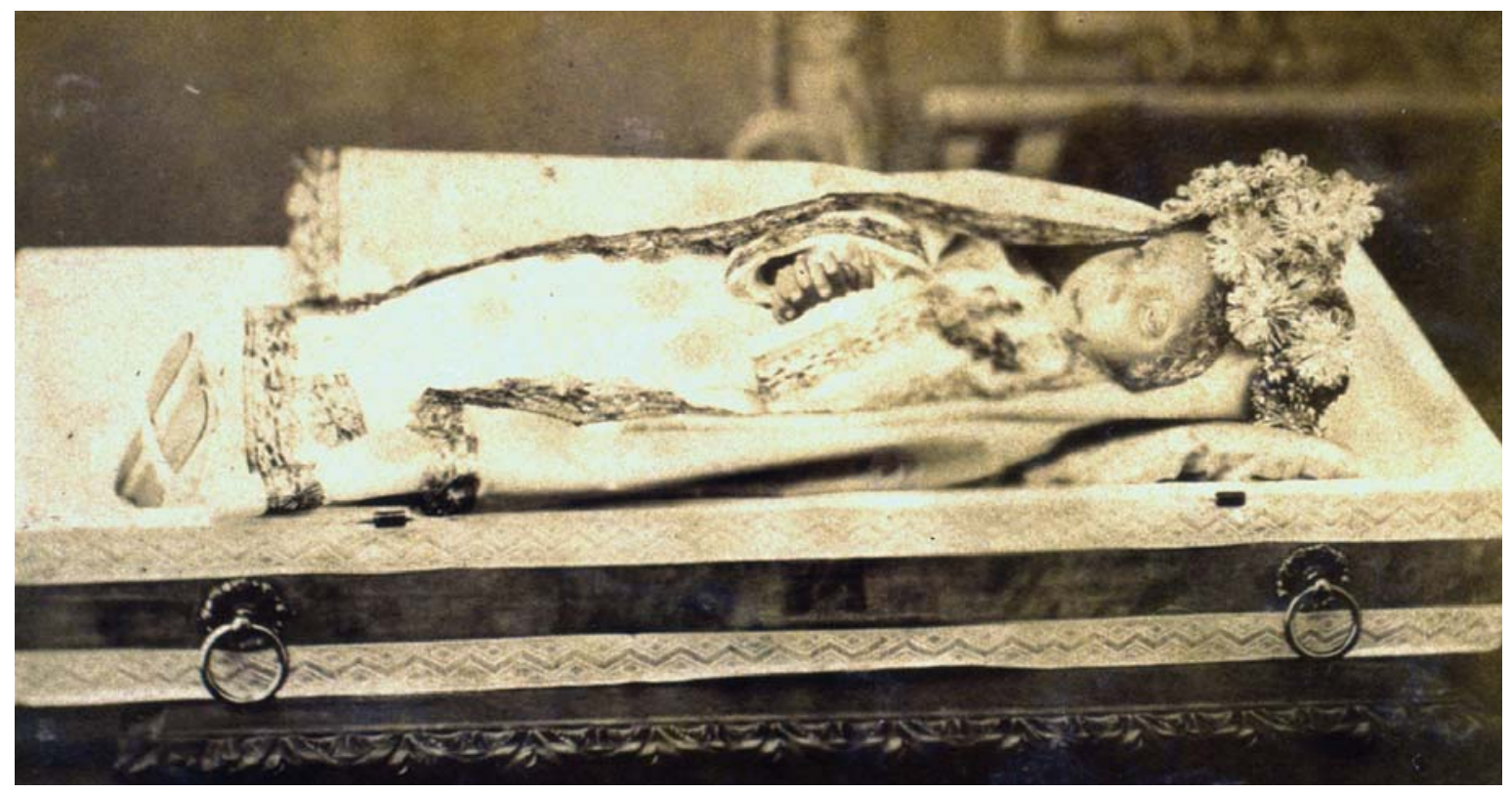

Figura 5 - Sem título. 1879. Fotografia de Militão Augusto de Azevedo. Acervo do Museu Paulista da Universidade de São Paulo.

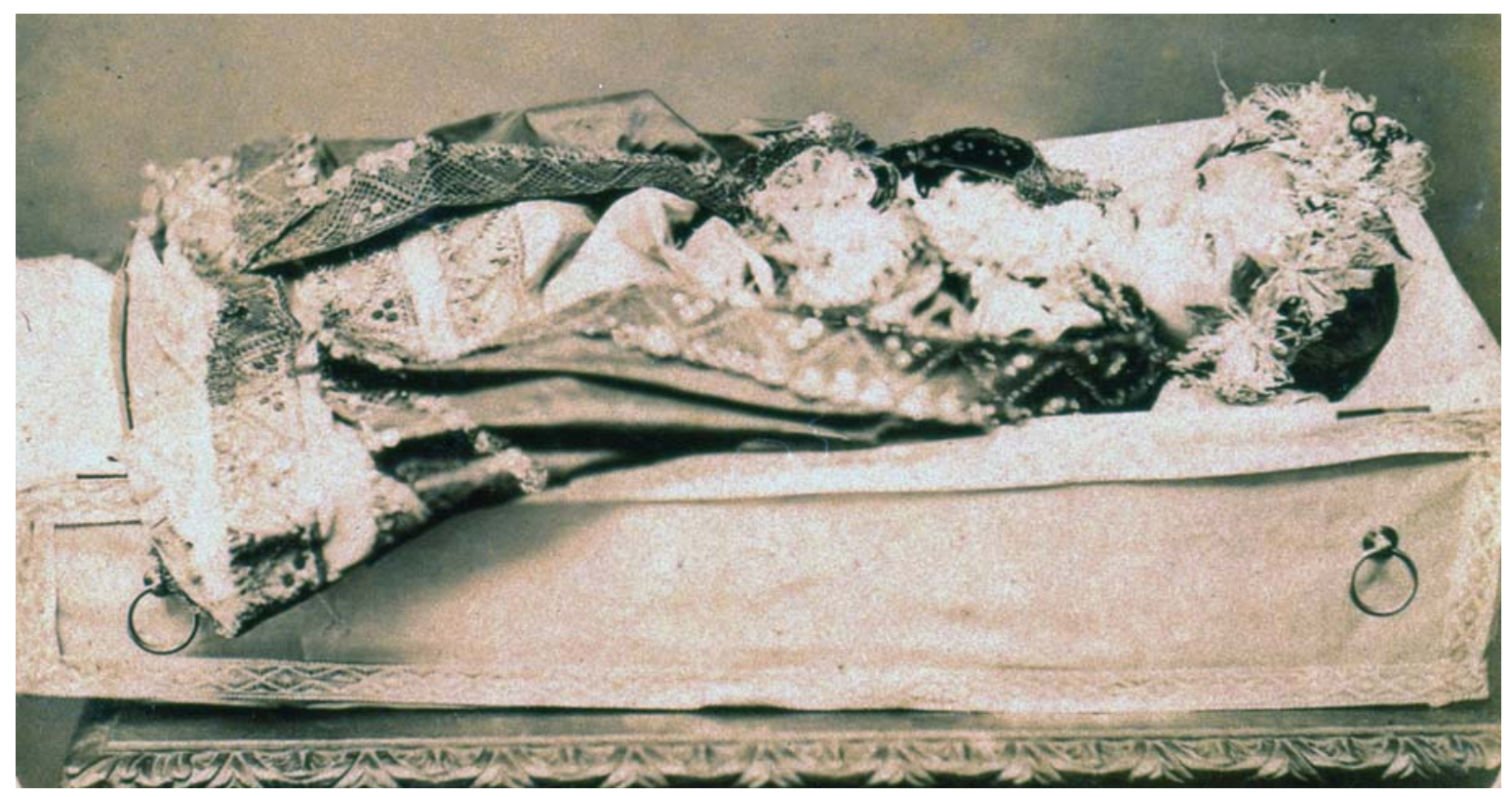

Figura 6 - Sem título. 1880. Fotografia de Militão Augusto de Azevedo. Acervo do Museu Paulista da Universidade de São Paulo. 


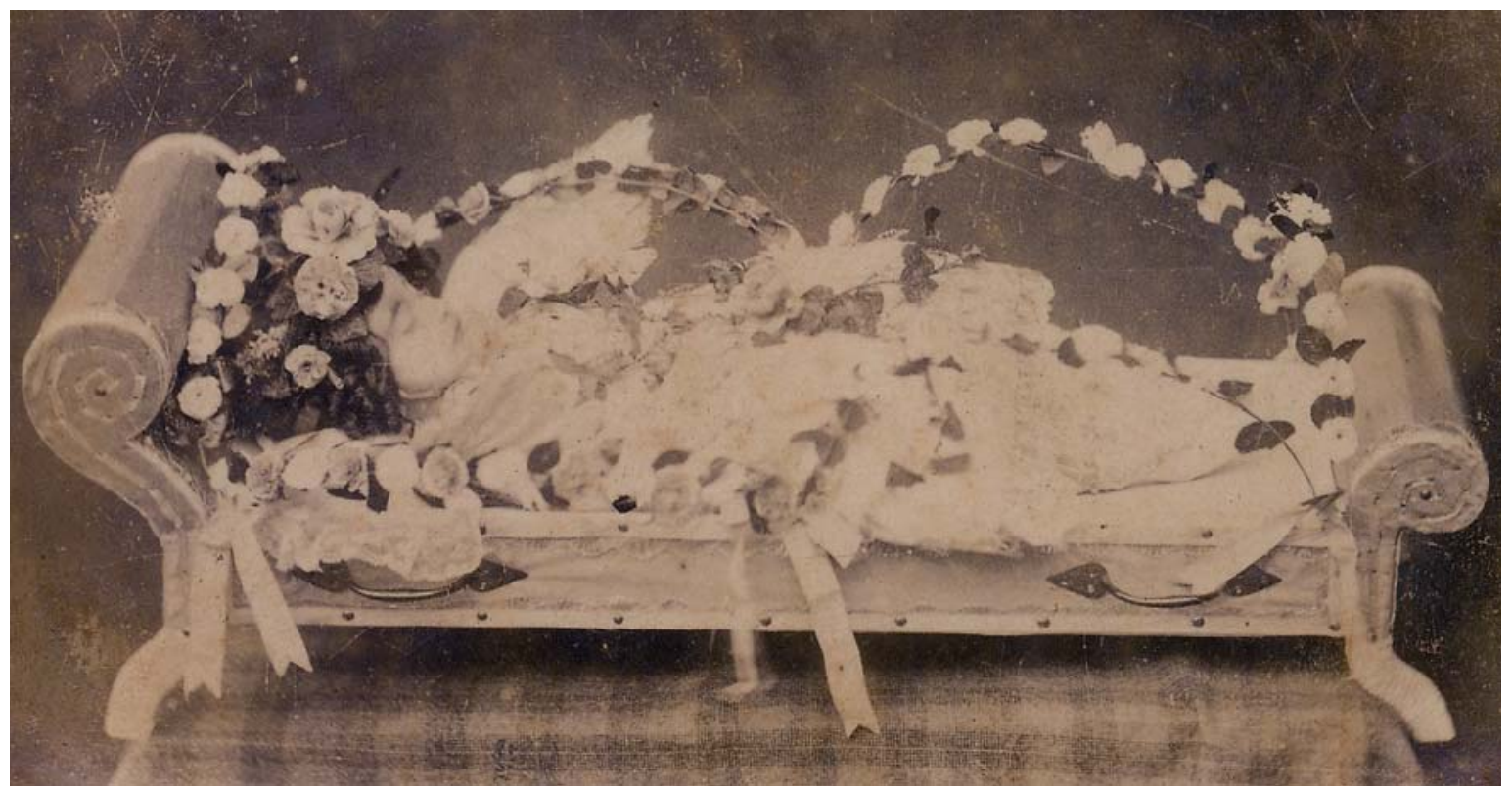

Figura 7 - Cadáver de criança, filho de Custódio José Maria Braga. 1880. Fotografia de Jerônimo Bessa. Acervo do Museu Paulista da Universidade de São Paulo.

importante dos rituais fúnebres infantis: a superexposição do morto?. A forma como eram organizados os rituais fúnebres infantis parecia, de fato, ser concebida de modo a atender ao desejo de permitir que o "anjinho" fosse visto por todos, a começar pelo fato de esses enterros, ao contrário dos de adultos, serem feitos de dia. Esta inversão dia/noite que caracteriza os "funerais de anjinho" está ligada, por sinal, com aquela que João José Reis ${ }^{10}$ observou nas procissões fúnebres infantis no Brasil oitocentista, nas quais o defunto faz "visitas" (na medida em que o cortejo procura passar pelas principais ruas da cidade) ao invés de recebê-las, como acontece aos adultos. Com efeito, aos participantes desses cortejos, desincumbidos de prestarem auxílio espiritual ao defunto (dada a certeza de sua salvação), cabia uma única atitude, a de louvar e admirar o pequeno falecido, o que significaria não apenas colocar-se sob sua proteção, como também prestigiar sua família. Tal era o esforço para conseguir o máximo nesse sentido, que há notícia de que o cadáver da criança ia de pé, em andores, devidamente paramentado e amarrado a uma estrutura vertical lo absoluto estranhamento com que isso nos aparece hoje sinaliza o teor das transformações que tiveram lugar nas práticas e representações da morte da criança ao longo desses dois séculos). Há indícios de que esse costume ainda era comum em algumas cidades no primeiro quartel do $\mathrm{XIX}^{{ }^{11}}$, para depois cair em desuso. Até mais tarde, todavia, como fazem testemunho outros relatos ${ }^{12}$, foi comum o uso de estrados, que também favoreciam a boa visibilidade do cadáver durante as procissões. Considerando a enorme importância que tinha o exercício de ver e mostrar o cadáver, em especial o da criança (como nos indica o uso específico dos andores para eles), a utilização da fotografia para o exercício de exposição
9. De fato, a primeira coisa de que o marinheiro norte-americano Charles Stewart recorda, acerca dos funerais infantis que observou na década de 1820 , era que "when children under seven years die, their bodies, in full dress, are exposed in procession through the streets" (STEWART, 1832, p. 49).

10. REIS, 1995.

11. EWBANK, 1976,p. 59. Um outro documento comprova a veracidade deste costume ao mesmo tempo em que assegura, se não sua continuidade para um período mais longo - em lugares menos urbanizados certamente -, no mínimo, que sua existência estivesse ainda fresca na memória coeva: o Ritual do Arcebispado da Bahia, de 1863 , assinalava ficar "reprovado o costume de se conduzir os cadaveres dos mesmos" (LEMOS, 1863, p. 144). 
12. Segundo John Luccock (1942, p. 39-40):"Estava eu parado junto ao portão de uma capela quando trazido por quatro pessoas, chegou um estrado contendo o que já tinha sido uma menina linda, prazeirosamente vestida e, como de costume, inteiramente à vista".

13. Como lembra João José Reis (1995, p. 114), para a Bahia da primeira a metade do XIX:"Primeira providência: preparar o defunto para o velório e tratar do funeral. O cuidado com o cadáver era da maior importância, uma das garantias de que a alma não ficaria por aqui penando".

14. "Embora não tenhamos informações precisas sobre os múltiplos sentidos atribuídos às mortalhas por nossos antepassados, o certo é que não eram um elemento neutro. Seu uso exprimia a importância ritual do cadáver na integração do morto ao outro mundo e sua ressurreição no fim deste mundo. Era uma representação do desejo de graça junto a Deus, especialmente a mortalha de santo, que de alguma forma antecipava a fantasia de reunião à corte celes te $[\ldots]$ Vestir o cadáver com a roupa certa podia significar, se não um gesto suficiente, pelo menos necessário à salvação" (REIS, 1995, p. 124).

15. Sobre os testamentos baianos da primeira metade do XIX, João José Reis informa que "Os que testavam deixavam instruções sobre como desejavam vestir-se para o funeral" " "para se ter tudo ao gosto, podia-se descer a minúcias" (REIS, 1995, p. 116).

16. Idem nota 11. Já Kidder (1980, p. 158), no fi- da criança morta, aparece, por conseguinte, como um desdobramento bastante natural e um uso compreensivelmente oportuno de um recurso novo e vantajoso (no sentido de perene) em prol de um costume já há muito apreciado, qual seja, o de contemplar e de dar a ver o defunto. Esse novo suporte, não obstante, também implicou uma nova conduta em relação à visibilidade da criança morta, e dela foi sintoma, conforme discutiremos adiante.

Se, como dissemos, a presença dos signos próprios dos rituais fúnebres nessas fotografias nos impede de entendê-las como apenas um derradeiro recurso para registrar a imagem do ente querido, a análise mais pormenorizada deles possibilita, por conseguinte, entrever mais claramente as representações tradicionais que cercam a criança morta. Com efeito, os cuidados aos quais é submetido o cadáver da criança para o período em questão têm um papel de suma importância ${ }^{13}$. Como constatei em minha investigação, à exceção do batismo, os rituais da morte infantil concentram-se no momento imediato após a consumação da morte. Durante grande parte do período estudado, e para todos os mortos (adultos e crianças), esses primeiros cuidados diziam respeito à preparação do corpo para que ele fosse velado, exposto e enterrado; e esses cuidados não eram menos importantes que os outros que the seguiam no rol do gestual fúnebre.

A esse respeito, a primeira coisa que em nossas imagens nos chama a atenção é o cuidado com que as crianças estão preparadas. Aqui também os significados desta disposição não estiveram restritos ao plano estético. Tendo origem em tempos em que a crença na separação entre corpo e alma após a morte não era algo bem definido, a idéia de ser a forma como se era enterrado a mesma como se entraria no Além chegou até o século XIX no Brasil. Em suma, um defunto adequadamente vestido poderia beneficiar-se disso no tocante ao destino que as potências celestiais the reservariam ${ }^{14}$. Essa concepção estava então de tal modo enraizada, que muitos, ao elaborarem seus testamentos, procuravam informar qual seria sua última roupa ${ }^{15}$. As crianças, apesar de não decidirem sobre isso (entre outras coisas por que não deixavam testamento), também deviam ser enterradas em trajes especificamente recomendados. $\bigcirc$ fato é que a mortalha da criança em nada devia à dos adultos mortos, o que é testemunho de que as crianças mortas eram objeto de notável atenção. Já nesse aspecto, os visitantes estrangeiros mostraram-se positivamente surpresos pelo esmero com que esses pequenos defuntos eram arrumados e expostos: "prazerosamente", "ricamente" são os termos por meio dos quais John luccock e Daniel Kidder descrevem a preparação das crianças mortas na Corte ${ }^{16}$.

No que se refere às mortalhas que aparecem nas fotografias aqui analisadas, constata-se, entre outras coisas, o uso do branco (Figuras 8 e 9). Esse costume, para a cidade de São Paulo, encontra apoio em outros e mais antigos registros. Segundo, por exemplo, o que nos dizem os livros de assentamento de óbito, o branco era, com enorme vantagem, a mortalha mais utilizada para as crianças, correspondendo a $65 \%$ do total de registros computados ${ }^{17}$, encontrada em $68,1 \%$ dos registros de livres, em $78 \%$ dos de escravos e em $88,9 \%$ dos de forros ${ }^{18}$. A isso acrescentamos a constatação de 


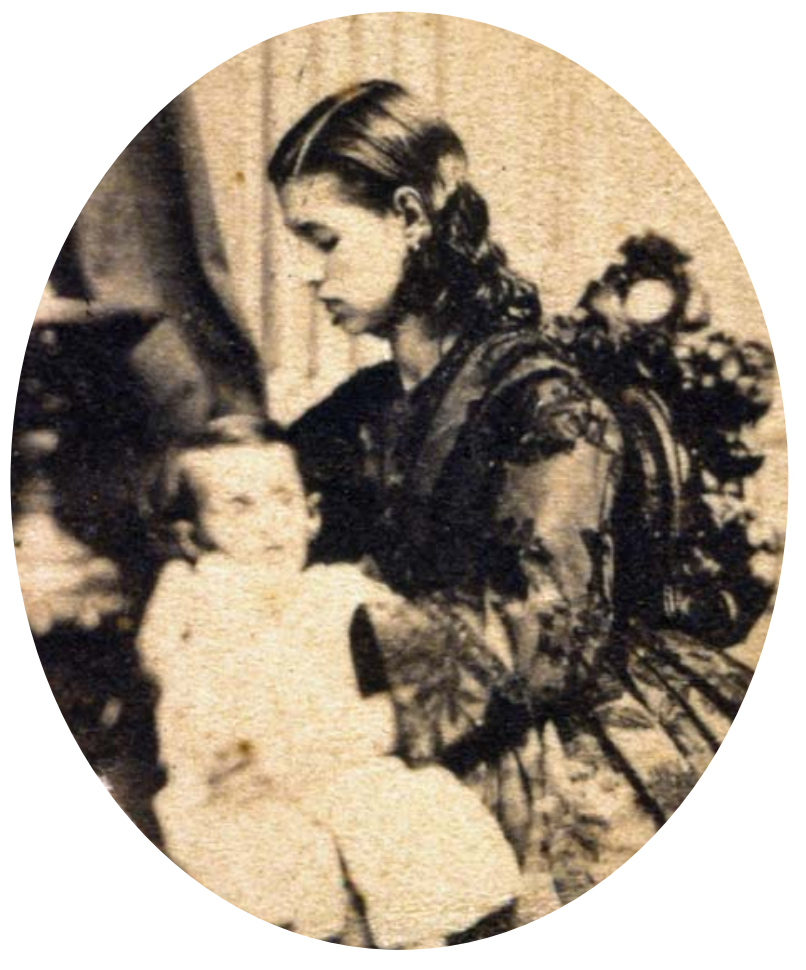

Figura 9 - Olga Marcondes de Matos. 1895. Fotografia de De Nicola. Acervo do Museu Paulista da Universidade de São Paulo.
Figura 8 - Sem título. 1865. Fotografia de Militão Augusto de Azevedo. Acervo do Museu Paulista da Universidade de São Paulo.

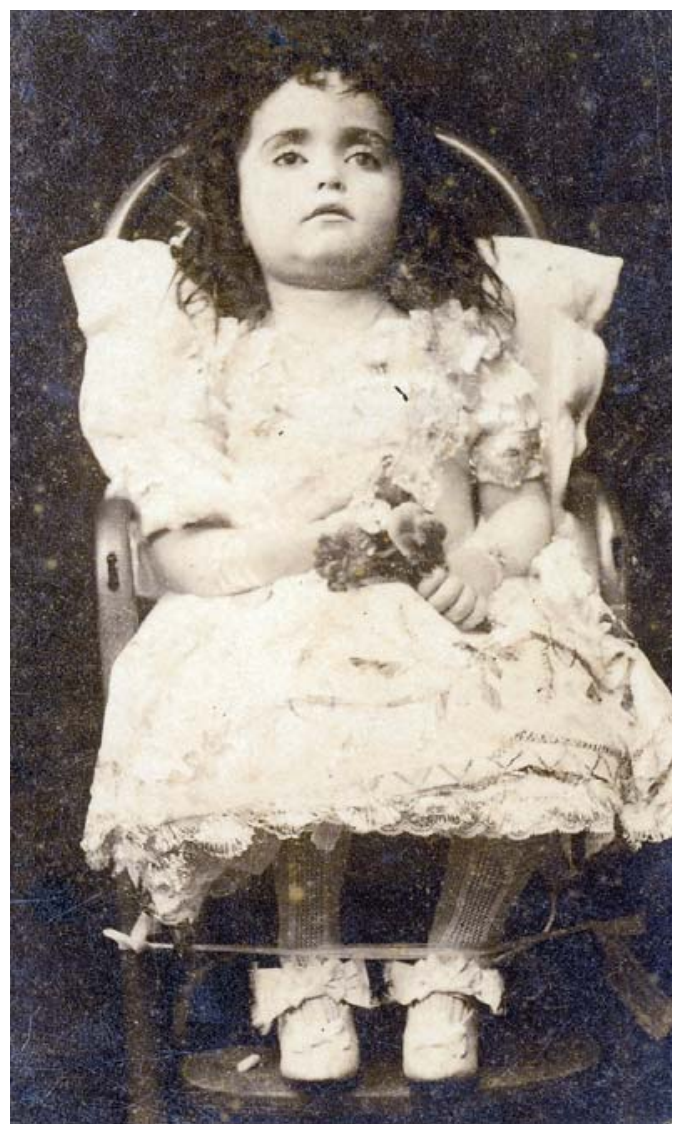


nal da década de 1830 presenciando um funeral, descobre "num ataúde aberto, o corpo da criança ricamente vestida e coberta de laços de fitas e flores".

17. Cf. Luiz Lima Vailat (2005, p. 98)

18. Idem, p. 97

19. "Related to Hellenis tic and above all to Roman traditions, Christian color symbolim was generally based on white, which was the color of joy, innocence, and purity. White was the color of the martyr, the candidatus exercitus ('white-clad army')" (ELIADE, 1987, p. 562)

20. Cf. Luiz Lima Vailati (2005, p. 98.

21. Domique Julia mostra como, desde o século XV, foi comum a veiculação por parte da Igreja e da cultura popular na Europa a imagem do sacrifício ritual das crianças (JULIA, 1998, p. 286-373). Sobre o assunto tratado, ver p. 292-301

22. Em seu compêndio sobre signos e símbolos da arte cristã, George Ferguson observa que "White has always been accepted as symbolic of innocence of soul, of purity, and holiness of life" (FER GUSON, 1961,p. 152); Segundo Chevalier e Gheerbrant a"arte cristã acabou por atribuir, num processo paulatino e sem fazer disso regra absoluta, o branco ao Pai, [...] à fé, [...] à castidade" (CHEVALIER; GHEERBRANT, 1995, p. 277); O dicioná rio de Ryston Pike lembra que "El blanco u oro se usa en todas las festividades principales de la Trinidad, de Cristo y de la Virgen María, asi como en las de los santos que fueran Confessores o Vírge- que a cor branca predomina também em outros elementos dos funerais de crianças, como mostraremos adiante. Quais são, por conseguinte, os possíveis significados dessa escolha? Nos primeiros tempos do cristianismo, o branco era a cor que representava os mártires da lgreja, para depois ser substituída pelo vermelho ${ }^{19}$ (esta última é, por sinal, a segunda cor mais utilizada nas mortalhas de criança na cidade de São Paulo ${ }^{20}$ e está presente em outros elementos que compõem a cultura material mortuária infantil; nas fotografias, alguns tons de cinza sugerem sua presença, como na Figura 2). Isso testemunha a existência de uma forte identificação entre a criança e os mártires, associação já observada por outros historiadores na Europa ${ }^{21}$, bem como entre a morte infantil e o sacrifício, nas quais já é possível entrever uma concepção que investe a criança de atributos de santidade.

Mas, no que diz respeito aos significados mais amplos e mais resistentes que essa liturgia tradicionalmente atribuía ao branco, os compêndios de semiologia cristã nos informam ser este o símbolo da alegria e, antes de tudo, da inocência e da pureza virginal ${ }^{22}$. A análise das mortalhas e das cores utilizadas nos funerais de adultos e crianças, além de confirmar a existência desse entendimento em que a criança esteve associada aos atributos de pureza e inocência, informa de onde, nesse registro, essa qualidade the advém, principalmente entre o mundo leigo. Nos rituais fúnebres brasileiros, a associação tradicionalmente feita entre a "inocência" infantil e a ausência do ato sexual fica explicitada pelo fato de serem as moças virgens também enterradas do mesmo modo que as crianças, ainda que isso contrariasse expressamente a vontade da Igreja ${ }^{23}$. Como a cor da alegria, o branco do hábito mortuário infantil se opõe à mortalha do adulto, muitas vezes de cor preta ou roxa, as cores da penitência ${ }^{24}$. A criança, já no que essa prática permite ler, dispensa essa atitude, assim como outros procedimentos normalmente utilizados para o ajuste satisfatório da balança das almas: devido ao estado de inocência com que morria, não havia necessidade de qualquer caução expiatória, só cabendo, pois, o rejubilamento. Sobre o branco, resta lembrar que ele sinaliza uma relação freqüentemente estabelecida nesses rituais, que é aquela feita entre a criança morta e a figura de Nossa Senhora - no caso, Nossa Senhora da Conceição, uma vez que é com essa cor que a Virgem se veste nas representações da Imaculada Conceição ${ }^{25}$, imagem cuja veste é usada preferencialmente nas crianças no Rio de Janeiro, como nos mostra o trabalho de Cláudia Rodrigues ${ }^{26}$

Por sinal, entre as fotografias analisadas, ficou registrado um costume muito difundido no Brasil do século XIX, o de vestir as crianças mortas com vestes de santos (Figuras 1, 3 a 6$)^{27}$. Nisto elas não diferiam dos adultos, visto serem deste tipo as mortalhas que de costume eram utilizadas como derradeira roupa. Isso estava de acordo a crença de que o falecido, vestido de tal modo, seria favorecido pela intervenção do santo cujo hábito escolhera por mortalha, o qual o receberia e o guiaria em direção ao Céu ${ }^{28}$. Assim, seu protetor em vida não Ihe faltaria na morte. Era, em suma, uma demonstração de fé le, para alguns, de despojamento, o que explicava o sucesso que tinham os hábitos das ordens mendicantes) que certamente seria reconhecida em tão decisivo momento. Era 
natural, por conseguinte, que se escolhessem santos de sua predileção ou patronos de sua irmandade. Era comum, como nos ensina, por exemplo, a passagem citada de Thomas Ewbank ${ }^{29}$, que se vestissem as crianças com o hábito do santo de seu nome: se a criança se chamasse Francisco, ia vestida com o hábito de monge (certamente devia ser o da ordem de mesmo nome). Vestindo a criança com as roupas deste ou daquele santo, os pais imaginavam garantir que seu rebento não ficaria desamparado no outro mundo, estando guardado sob os cuidados de seu homônimo. Como certamente não o fora enquanto era viva, não era indiferente aos pais o que poderia acontecer à criança quando morta.

Mas é possível afirmar que essa prática estava também relacionada com razões que são ainda mais específicas de uma certa sensibilidade para com a criança. Ela diz respeito a uma crença no papel de intermediária que a criança morta ocuparia entre os vivos e as autoridades celestes ${ }^{30}$. Essa função se assentava no estado de pureza que a caracterizava e que já garantira prerrogativas especiais à criança quando viva. Tal crença fica bem exemplificada em práticas como a participação dos pequenos nas procissões religiosas e nos rituais fúnebres tradicionais. Alceu Maynard, já em meados do século XX, registrou, no meio rural do país, o costume de deixar às crianças a realização da encomendação dos corpos, etapa de extrema importância nos funerais ${ }^{31}$. Quando morta, estando em contato mais direto com os santos, o poder de intermediação entre os homens e as entidades celestes era potencializado. Mais do que nunca, escolher a mortalha de um santo em particular significava a possibilidade de melhor explorar esse poder, tendo em vista um objetivo preciso, uma vez que, no universo da religiosidade popular, cada santo era "especialista" em determinado tipo de providência. Levar em conta essa concepção nos permite pensar em mais algumas razões para a preferência de algumas mortalhas em relação a outras; no nosso caso, a freqüência do branco nas crianças fotografadas, que, como vimos, esteve liturgicamente associado às vestes de Nossa Senhora da Conceição.

João José Reis, em seu trabalho sobre a Bahia, mostrou com notável sensibilidade como a preferência a esta e a outros santos para a mortalha das crianças soteropolitanas esteve relacionada à questão da procriação ${ }^{32}$. E isso permite entender a preferência que foi dada a determinadas mortalhas para a criança morta. Ora, com a morte de um filho, não é incomum o desejo de se ter outro. E que outra forma seria mais eficiente de assegurar isso do que preparar tão especial mensageiro ao encontro de santos que certamente atenderiam ao seu pedido?

A condição particular da criança morta seria ainda mais manifestamente demonstrada por meio do uso de uma outra mortalha, presente em uma das fotos aqui analisadas: as vestes de anjo (Figura 7). Esse tipo de mortalha, composto de plumas e sedas e muitas jóias - e cujo uso, segundo Claudia Rodrigues, aumentou bastante ao longo do século ${ }^{33}$-, chamou a atenção de estrangeiros como Stewart e Candler, que estiveram no Rio de Janeiro em 1829 e 1852, respectivamente ${ }^{34}$. Thomas Ewbank descreve a de São Miguel Arcanjo, que, segundo ele, era mais comum entre as crianças mais velhas: o nes, pero no Mártires" (PIKE, 1960, p. 107); ver, também, nota 19.

23. O Ritual do Acerbispado da Bahia, do Pe.Lourenço Borges de Lemos, estabelecia que "Sommente aos menores de sete annos é permittido, além da palma e capella a mortalha de gala: ficando prohibido o costume de se amortalhar de gala e côres os cadáveres das virgens adultas, ás quaes unnicamente são permittidas palmas e capellas, $\mathrm{e}$ algumas flores naturaes sobre a mortalha, que poderá ser rôxa" (LEMOS, 1863, p. 118)

24. O Dicionário de Símbolos de Chevalier e Gheerbrant (1995, p. 277) lembra que, deste modo, a arte cristã atribui cores às qualidades espirituais: "o verde à esperança, o branco à fé,o vermelho ao amor e à caridade, o preto à penitência" (grifo meu). Quanto ao roxo, Royston Pike observa que "El morado es el color de la penitencia, se emplea en el Adviento, la Cuaresma y las vigilias" (PIKE, 1960, p. 107).

25. George Ferguson assinala que "White is worn by Christ after his Ressurection. It is also worn by the Virgin Mary in paintings of the Immaculate Conception" (FERGUSON, 1961, p. 152).

26. No caso do Rio de Janeiro, o dados de Cláudia Rodrigues nos mostram que esta veste era uma das mais comuns entre as crianças escravas, correspondendo a $16,6 \%$ dos respectivos registros - só perde para o hábito de Nossa Senhora da Conceição $(31,3 \%)$ e para a veste de menino do coro (19,0 \%). A população branca e forra do Rio de Janeiro demonstra uma preferência sensivelmen- 
te menor por essa mortalha: $4,0 \%$ e $4,2 \%$ respectivamente (RODRIGUES, 1997, p. 212).

27. Idem, p. 210 e 211

28. É nesse sentido que João José Reis explica um dos motivos da grande preferência, entre os adultos baianos, por serem enterrados com o hábito da ordem franciscana. Segundo o autor "A iconografia franciscana indica que o santo tinha um lugar destacado na es catologia cristã. Na cidade da Bahia, uma pintura no teto da desaparecida catacumba do Convento de São Francisco [...] retrata o santo resgatando almas do Purgatório, que visitava periodicamente com essa finalidade" (REIS, 1995, p. 117).

29. Thomas Ewbank, no Brasil entre 1845 e 1846 , deixou-nos uma descrição bastante interessante sobre esse costume "As crianças com menos de 10 e 11 anos são vestidas de frades, freiras, santos e anjos. Quando se veste de São João o cadáver de um menino, coloca-se uma pena em uma das mãos e um livro na outra Quando é enterrada como São José, um bordão coroado de flores toma o lugar da pena, pois José tinha um cajado que florescia como o de Abraão. A criança que tem o mesmo nome que São Francisco ou Santo Antônio usa geralmente como mortalha um hábito de monge e capuz [...] As meninas representam 'madonas' e outras figuras populares" (EWBANK, 1976, p. 59).

30. O francês Jean-Baptiste Debret, em 1816, diznos o seguinte sobre a grande mortalidade infantil entre os escravos "a perda desta criança es crava dá à dona da casa a consolante esperança de cadáver é vestido com uma túnica que vinha acompanhada de uma saia curta presa por um cinto; na cabeça, um capacete de papelão dourado; e era calçado com "apertadas botas vermelhas", tendo presa à mão direita uma espada ${ }^{35}$. Paralelo já evidenciado no uso do termo "anjinho" para designar a criança morta, a morte não era a única circunstância em que a criança tinha oportunidade de se vestir como tal. Muitos foram os viajantes que, durante todo o século XIX, comentaram as procissões em que crianças (no geral menores de sete anos, como salientam os relatos) saíam representando anjos, cujas descrições deixam evidente o gosto pelo exagero: asas artificiais, perucas, profusão de pedras, etc. ${ }^{36}$ Além de reafirmar uma série de valores agregados à criança morta, como o seu estado de pureza que toma corpo na figura do anjo, o uso das vestes angelicais acentuam igualmente outras características comuns a todas as dimensões dos enterros dos inocentes, como é o caso da ostentação material, que nelas tem um suporte especial. É interessante assinalar, por fim, que a associação entre a criança e o anjo mantém relações distantes com a concepção do papel de intercessora que se atribui à criança. $\bigcirc$ recente trabalho de Jean Delumeau - O que sobrou do paraíso? - faz referência a um manuscrito do século XII de autoria da abadessa do mosteiro de Hohenbourg (hoje SainteOdile), Alsácia, que descreve a geografia do paraíso conforme fora difundida por Pseudo-Dionísio ${ }^{37}$, no qual os anjos - que no texto da abadessa se encontram na mesma ordem (da hierarquia celeste) que os pagão salvos - "estão em contato direto com os homens" ${ }^{38}$. Nesse sentido, cabe a observação de que, no que se refere à morte infantil, a realidade do Brasil Colônia lassim como em grande parte do Império), caracterizada pela impossibilidade de fazer valer a ortodoxia tridentina, deu margem para o enraizamento de concepções escatológicas de um catolicismo bastante antigo.

Além das mortalhas, é notável, nas fotografias, a existência de outros elementos tradicionais que compunham o aparato material da criança morta, como a presença de flores, em especial aquelas arranjadas em forma de coroa (Figuras 1, 3, 5 a 7), ou do ramalhete de flores (melhor identificável nas Figuras 2 e 9). As descrições dos viajantes para outras cidades ${ }^{39}$ apontam o seu uso junto às crianças mortas ao longo do XIX. Quanto à coroa de flores, esta possui, nos escritos judaicos-cristãos, segundo Chevalier e Gheerbrant, mais de um significado possível, alguns bastante sugestivos para o assunto estudado aqui. Num deles, a coroa representa a salvação eterna que vem como recompensa a uma vida regida pela fidelidade à causa da fée ${ }^{40}$. Com efeito, a idéia do ingresso na Corte Celeste está bastante de acordo com uma conduta ritualística que associa a morte infantil à "boa morte". O outro significado estaria ligado ao batismo, e sua imagem está relacionada à do paraíso, uma vez que alguns textos assinalam que é da árvore da vida que são feitas as guirlandas dos iniciados ${ }^{41}$. Como se vê, temos aqui, mais uma vez, a presença de um elemento a assinalar a crença na certeza da salvação infantil.

E há os caixões (Figuras 1 a 7). Considerando a presença de outros elementos do aparato fúnebre nas fotografias analisadas, seria surpreendente eles não aparecerem. $\bigcirc$ que faz de sua participação algo bastante significativo 
- no que toca a uma atitude pretérita para com a criança morta - é o fato, já exposto acima, de que entre os interesses que presidem a confecção dessas fotografias há aqueles que reeditam uma tendência tradicional, que é a de permitir que o cadáver seja visto. Esta antiga função do caixão, ainda que subsista atualmente, ganhou importância secundária face à função moderna que é a de, sobretudo, garantir o isolamento e individualização dos restos mortais do falecido. Com efeito, no início do século XIX, os esquifes tinham exclusivamente a função de transporte e de suporte para a exposição do cadáver, função evidenciada pela existência de modelos sem tampa e também pelo fato de serem alugados e não vendidos, tal como nos informa, por exemplo, a descrição e as ilustrações detalhadas dos serviços funerários brasileiros que nos faz o artista Jean-Baptiste Debret, quando esteve na Corte entre 1816 e 183542. Com efeito, em algumas das imagens que escolhemos, somos informados de como isso se dava: o esquife servia de anteparo para o cadáver que, para uma maior visibilidade, era inclinado frontalmente (Figuras 3, 5 e 6) ou lateralmente (Figuras 1 e 5). Nesse sentido, o que fica em primeiro plano nas fotografias é o tradicional uso dos esquifes como suporte para expor o cadáver, lembrando também que neles estão presentes outros elementos associados à representação tradicional da morte infantil que já assinalamos: alguns féretros são forrados de tecido branco (Figuras 4 e 6); outros se distinguem pelo uso de um tecido mais escuro (vermelho?), mas com faixa branca ao longo do féretro (Figuras 1 a 3, 5).

Como se vê, nas fotografias aqui analisadas é indiscutível a presença de elementos que, no século XIX, estavam tradicionalmente relacionados a uma determinada prática e representação da morte menina. No entanto, esse material é também indicador de algumas mudanças importantes que se operaram nesse âmbito, ainda que isso ocorra de forma menos evidente do que em relação aos costumes assinalados acima. Tal constatação nos leva, em primeiro lugar, a pensar na própria emergência da fotografia de criança morta para a sociedade em questão, o que já é, em si mesmo, uma mudança nas práticas fúnebres infantis. De acordo com o que mostramos nas linhas anteriores, não seria errôneo concluir que, em grande parte, a fotografia revelou-se como mais um instrumento entre outros para a veiculação de antigas práticas e valores nesse âmbito. Tomálas apenas assim, não obstante, seria fazer vistas grossas para as mudanças importantes que elas sinalizam. Com efeito, é isso que se constata quando levamos em conta outras questões envolvidas na prática específica de fotografar crianças mortas e armazenar as imagens em álbuns. Essas questões dizem respeito à prática de fotografar os membros da família na sociedade ocidental, uma vez que isso anuncia novos valores, em última instância, modificadores das práticas e representações da morte menina.

Em seu ensaio sobre a memória, Jacques Le Goff assinala o advento da fotografia - ao lado dos monumentos aos mortos depois da Primeira Guerra Mundial - como uma das manifestações importantes da "memória coletiva" que marcam nossa contemporaneidade, a quem coube multiplicar e democratizar a memória, ao mesmo tempo que deu condições para melhor apreender aquilo que o tempo transformou ou suprimiu e a "evolução cronológica" dessas um anjinho que por ela interceda no céu" (DEBRET, 1989, p. 176).

31. Cf. Alceu Maynard Araújo: "Assinalamos a participação de alguns meninos na 'recomenda'. A presença de meninos é um dos índices de continuidade destas tradições populares porque é o grupo das crianças e das mulheres o melhor guardador e transmissor do folclore" (ARAÚJO, 1964, p. 65).

32. É oportuno, nesse sentido, mencionar a veste de São João Batista, que, no Rio de Janeiro do XIX, também aparece para as mortalhas infantis, apesar de estar em número pequeno em relação a outras $(3,3 \%$ contra, por exemplo, $31,3 \%$ de vestes de Nossa Senhora da Conceição). J. Reis lembra que ele foi fruto de uma união de pais tidos como estéreis. No cerimonial fúnebre infantil, para além dos cuidados tendo em vista a salvação do morto e a proteção dos vivos, a eles se soma uma outra preocupação: a manutenção da linhagem, que é comprometida com a perda filial."As altas taxas de mortalidade infantil tornavam a sobrevivência das crianças uma preocupação fundamental das famílias baia nas. [...] Algumas mortalhas infantis parecem evocar mitos de fertilidade, como as de Nossa Senhora da Conceição e a de São João [...] Nossa Senhora é o arquétipo cristão de mãe, mas sua qualidade de conceber, de gerar vida é o aspecto aqui evocado. A Senhora da Conceição era uma espécie de deusa brasileira da fertilidade" (REIS, 1995, p. 120).

33. Cf. Cláudia Rodrigues: "Quando reapareceram as referências [às morta- 
lhas nos livros de óbito da freguesia do Santíssimo Sacramento], a partir de 1865 , as vestes de me nino do coro, bem como grande parte das demais já haviam dado lugar às vestes angelicais e/ou virginais" (RODRIGUES 1997, p. 211).

34. Assim o americano Charles Stewart descreve os mortos "under seven years of age" que encontra no Brasil entre 1829 e 1930: "the cheeks being painted, the head crowed with artifitial flowers and the whole figure sometimes dressed in imitation of an angel, with expanded wings of tinse and gauze" (STEWART, 1832, p. 49). Já John Candler, no Brasil em 1852 observa que "when a child dies the remains of the deceased child are decked out to represent anAngel; the coffin is profusely adorned" (CANDLER; BURGESS, 1853, $\mathrm{p}$ 44). Ainda que diga respeito ao Rio Grande do Sul,é bastante interessante a descrição do ex-te nente alemão Carl Sie dler, em 1835. Segundo ele, o "pequeno cadáver jazia como um boneco de cera sobre a cama de gala, enfeitada de coroas e flores, mãozinhas cruzadas, trajado como um anjo que como alva pomba irá diretamente para o céu" (SIEDLER, 1980, p 155].

35. Cf. Thomas Ewbank (op. cit., p. 59)

36. É Debret (op. cit., p $40, n .4)$, que esteve na Corte no início do século XIX, quem nos dá a descrição mais detalhada dos seis anjos que observa na procissão do enterro. Sobre isso, ver também Ernst Ebel (op. cit. p. 38 e 134); Ferdinand Denis (1980, p. 144); Daniel Parish Kidder (op cit., p. 137); Thomas Ew- mudanças ${ }^{43}$. É nesse duplo processo - de disseminação de um veículo de memória e do desenvolvimento de uma nova sensibilidade para com a passagem do tempo - que podemos compreender melhor os significados das coleções fotográficas que têm como objeto o universo familiar. De fato, entre as possíveis funções dos álbuns de fotografia de família, está a "materialização" das reuniões sazonais que são manifestações da unidade social, como lembra Michele Perroł ${ }^{14}$. A escolha se orienta para os acontecimentos cujos registros melhor se prestam como "monumentos" da identidade familiar, tornando possível, por conseguinte, as visitações periódicas ao "menor denominador comum do passado". Por isso é que Pierre Bourdieu aponta ser essa lógica seletiva a que faz do álbum de família a expressão da "verdade da recordação social" desse meio ${ }^{45}$. Já assinalamos antes, como sintoma da permanência da valorização desse evento, a importância que tradicionalmente tinham os funerais de criança e o fato da eleição desse motivo entre os acontecimentos que mereciam registro fotográfico. Agora, quando tomamos o registro fotográfico pelo uso que dele se fez, surge um aspecto novo: fotografia do "anjinho" não apenas recorda um evento que era fundamental na afirmação da família perante a sociedade (cujo investimento material e simbólico tinha papel estratégico nisso), mas permite o exercício da celebração da unidade familiar, ao registrar um acontecimento cuja periodicidade dá lugar aos reencontros que reforçam a identidade da comunidade de sangue.

Esse novo significado fica mais evidenciado pela segunda função do álbum de família, lembrada por Perrot, qual seja, a de ser a "galeria dos antepassados" e, dessa via, permitir a "visualização da linhagem"46. As possibilidades abertas com isso revelam-se de diversos modos. Primeiramente, conforme observa Anne Martin-Fugïer, o registro desses conjuntos, muitas vezes organizados cronologicamente, propiciam uma nova percepção do crescimento e envelhecimento dos participantes do círculo familiar ${ }^{47}$, modo pelo qual a já citada atuação das fotografias na constituição de uma sensibilidade temporal diferenciada manifesta-se nos álbuns de família. É nesse sentido que Alain Corbin ressalta o seu papel como registros visuais da inexorabilidade do tempo e da morte, modalidade em que a fotografia assume especialmente a função que, como lembra o autor, Susan Sontag dá a ela, a de memento mori ${ }^{48}$. Se as fotografias de crianças mortas não se prestam muito bem, a meu ver, a figurar a associação entre tempo e morte - visto que lembra que a morte ignora a idade - Alain Corbin enumera outras funções desses corpora iconográficos que nos interessam particularmente. Ele nota que as fotografias familiares propiciam a representação dos membros do grupo familiar que a morte ou apenas a distância física se encarregariam de relegar à absoluta ignorância ${ }^{49}$. A "posse simbólica" da fotografia, que faz dela um substituto ao retratado, além de reforçar as relações familiares (ainda que estas mudem de natureza, deixando de ser "orgânicas" para se tornarem "visuais"), ao modificar "as condições psicológicas da ausência", revela-se um eficaz lenitivo à sensação de perda causada pela distância e, sobretudo, pela morte ${ }^{50}$.

Como já é possível perceber, essas observações nos permitem voltar ao problema das motivações que presidiam as encomendas das imagens de 
crianças mortas com uma atenção renovada. A constatação do papel das coleções de fotografias da família como referencial mnemônico dos familiares/antepassados ausentes, e o papel que nisso têm os retratos de crianças mortas, é-nos oferecida pela propaganda que fazem, no século XIX, os profissionais da câmara escura, quando a prática ganha um sentido mais próximo a nós. Conforme já comentamos de passagem, o estudo de Keith McEroy sobre - Peru assinala que o argumento pelo qual os fotógrafos estimulavam o registro de crianças mortas consistia na observação de que esta seria a única e última oportunidade de acrescentar à memória familiar a imagem dos que partiram prematuramente $^{51}$. É bem provável que essa motivação estivesse presente no costume compartilhado pelos brasileiros. Como lembra Ana Maria Mauad, no início da disseminação do hábito de mandar fotografar-se no Brasil, a partir da segunda metade do século XIX, as idas aos estúdios com essa finalidade (cujo custo equivalia ao valor de um "sapato simples") limitavam-se, "entre as famílias urbanas de renda média", a uma ou duas vezes ao ano ${ }^{52}$. Nessas condições, não nos surpreende que, nas famílias que já haviam aderido à nova modalidade de reprodução imagética, muitos de seus membros morressem sem que jamais tivessem oportunidade de fotografar-se, e esse era especialmente o caso das crianças que morriam em tenra idade. Essa constatação oferece um significado adicional àqueles de natureza religiosa lque reafirmam a importância numinosa da criança morta e do evento que marca essa passagem), que já esboçamos antes, atribuídos ao fato da maior freqüência (exclusiva mesmo) das fotografias de crianças mortas não só entre as dos mortos adultos, mas também no conjunto das imagens de crianças (em especial as de colo) constantes no acervo do qual retiramos as imagens analisadas. É importante observar, por fim, que essa hipótese fornece uma das possíveis razões para uma questão fundamental para nós aqui: a rapidez com que a prática de fotografar crianças mortas entra em desuso no início do século XX. Uma vez que a prática devia estar vinculada, entre outras coisas, aos custos do registro fotográfico e, por conseguinte, à freqüência com que a população usufruía desse recurso, temos razões para pensar que o seu barateamento e a maior possibilidade de fotografar indivíduos, tão logo nascessem, estão diretamente relacionados com o desaparecimento de imagens de crianças mortas. A presença - nos cemitérios paulistanos e cariocas, em túmulos de crianças das primeiras décadas do século XX - de fotografias destas quando vivas e nas mais variadas idades, não deixa de vir em apoio a essa última constatação.

Entendida, por conseguinte, como um recurso para o único, ou ao menos último, registro daquele que prematuramente partira, ganham sentido alguns aspectos que aparecem nas imagens selecionadas neste artigo. Nelas, a preparação do cadáver, a escolha da posição em que era fotografado e demais cuidados parecem de algum modo estar relacionados mais propriamente ao objetivo de guardar a imagem do falecido de forma a mais próxima de quando este vivia, contornando, desta feita, a transformação que a morte já se encarregara de iniciar. Com efeito, algumas imagens, diferentemente das que analisamos acima, procuram, senão esconder, ao menos suavizar os indícios bank (op. cit., p. 96 e 160); e Oscar Canstat (1975, p. 208).

37. Segundo Jean Delumeau, "uma das pranchas evoca a corte celeste e refere-se de maneira evidente ao esquema do Pseudo-Dionísio, postulando, como ele, uma correspondência entre a hierarquia dos espíritos celeste s e a dos eleitos" (DELUMEAU, 2003, p. 41). O autor esclarece que, "Na realidade, o Pseudo-Dionísio parece ter sido um sírio que escreveu no fim do século V ou no começo do século VI.Aparentemente, era um neoplatônico convertido ao cristianismo" (Idem, p. 39).

38. Ainda Jean Delumeau (op. cit., p. 40).

39. Sobre um funeral infantil na Capela Real, no Rio de Janeiro, em 1824, Ernest Ebel (op. cit., p. 135) escreve: "A custo e bem de perto, pude ver, sob as flores e os enfeites dourados, o corpo de uma criança recém-nascida". Nos últimos anos da década de 1830, Daniel Kidder (op. cit., p. 158) recorda-se de ver, "num ataúde aberto, o corpo da criança ricamente vestida e coberta de laços de fitas e de flores". Já Ferdinand Denis (op. cit., p. 148), em 1838, observa que "Com freqüência encontram-se, nas ruas do Rio ou nas de São Salvador, uma dessas pequenas criaturas, rodeadas de flores artificiais, repousando num pequeno ataúde que um pano bordado envolve". Outros viajantes, em outros lugares do Brasil, observam o mesmo costume. James Wetherell, em 1860, em Salvador, sobre funerais infantis nota que "The corpse gaily dressed is exposed to view, surrounded with flowers 
and a gilt crown upon the head" (WETHERELL, 1860 , p. 111). Na passagem citada na nota 32 Carl Siedler (op. cit., p. 156) observa no Rio Grande do Sul, em 1835 , o mesmo uso de flores e coroas no funeral de "anjo" que ele presencia.

40. Segundo os autores "A imagem da coroa está relacionada, nos escritos judaicos-cristãos, com modos os mais diversos de representação" (op cit., p. 290). Um deles é "A coroa do atleta vitorioso nos jogos e combates do estádio. É essa realidade concreta que o cristianismo primitivo transpõe num registro espiritual e religioso. A vida do cristão implica, na sua fidelidade, num esforço sustentado [...] A vitória, e a coroa, que constitui o seu prêmio, não são mais comparadas a uma recompensa merecida por uma vida moral exemplar, mas à salvação eter na, concedida àquele que, levando a sério o Evangelho, viveu com um único fito, o de honrá-lo" (op. cit., p. 291)

41. O outro significado, segundo Chevalier e Gheerbrant, "aproxima da coroa a guirlanda que os iniciados recebem nos cultos que têm mistérios [...] É lícito indagar se não conviria evocar que simboliza a iniciação cristã [...] É fácil observar que, nesses textos [as Odes de Salomão] a imagem da coroa está indis soluvelmente ligada à do paraíso, uma vez que é a árvore da vida que fornece os materiais de que a coroa será feita" (op. cit. p. 290).

42. Segundo Debret,"Distinguem-se nos serviços funerários brasileiros, dois tipos de esquifes para exposição e transporte dos corpos que são em (fossem biológicos, fossem aqueles relacionados aos elementos ritualísticos, caixão, coroa etc.) de que o retratado era uma criança morta. Esse é o caso da menina fotografada em 1878, no Rio de Janeiro, no estúdio de Pacheco, Menezes \& Irmãos (das fotografias analisadas essa é a única que não faz parte do acervo do Museu Paulista e encontra-se no Museu Casa de Benjamim Constant $)^{53}$. A imagem obtida cria a ilusão imediata de que a retratada encontrase em sono profundo. Essa disposição, ainda que lembre uma antiga representação da morte (como se observa, por exemplo, nas esculturas presentes em túmulos de crianças nos cemitérios brasileiros), os trajes mundanos e a almofada na qual o corpo está apoiado sustentam a confusão, deixando que a cor do vestidinho, o ramalhete à mão e o rigor do corpo nos precisem a informação.

Essa impressão é radicalmente acentuada na fotografia de Olga Marcondes de Matos (Figura 9) produzida pelo estúdio de De Nicola, em 1895. Tal como a anterior, só a cor do vestido e o ramalhete de flores permitem saber que se trata de um cadáver. Mas é por meio desses dois elementos - com uma função que, pode-se dizer, opõe-se àquela dos cadáveres anteriormente discutidos e que, por esse motivo, não faz dele algo deliberadamente exposto mas sim mal escondido - que podemos ter a certeza de que estamos diante de um retrato de criança morta, tal é a preocupação da composição em apresentar o cadáver como se estivesse vivo: é a presença de fitas, cuja função é prender o corpo a uma cadeirinha e, desta forma, arrumar a criança de modo que pareça naturalmente sentada. Acrescente-se a isso o cuidado que se teve em fotografála com os olhos abertos, e o resultado é a facilidade com que a retratada parece mesmo estar viva, nas primeiras vezes em que the deitamos os olhos. À vista dessa imagem, não podemos deixar de pensar no relato feito a Ewbank sobre as procissões em que a criança morta era levada em pé em andores (ver nota 10), cuja impressão mais imediata é a de que ela estava viva. É indiscutível que estamos em presença de elementos comuns de sensibilidade, o que reforça as constatações feitas na primeira parte desse artigo acerca das continuidades reveladas pelas fotografias de crianças mortas. Não obstante, a presença dessa identidade não esconde uma diferença fundamental de ênfase nesses elementos. No primeiro caso, não era tanto o desejo de restaurar o aspecto da criança de quando esta era viva, mas sim de utilizar o cadáver como materialização simbólica do novo estatuto espiritual da criança; aqui, parece que a intenção é sobretudo recuperar o aspecto da criança quando ela estava viva.

Outra fotografia, a mais antiga analisada aqui, de 1865, oferecenos a mesma impressão das duas anteriores, embora, a despeito de ser mais velha, também sinalize para novas atitudes em relação à morte infantil (Figura 8). Nesta, a estratégia implicou não só em retirar da criança qualquer elemento simbólico (fora a roupinha branca) que a associe com a morte, mas também em fotografá-la no colo de um adulto (sua mãe, presume-se). Não obstante, é a ele que cabe informar a condição da criança: isso se faz através da roupa escura que nos remete ao luto, e, sobretudo, pelo olhar grave que dirige à criança. Percebe-se também que a mãe é a figura central da imagem (a propósito, o foco 
da lente está sobre seu rosto). Mauad nos dá notícia de retrato semelhante: é o retrato de Arthur, filho de um representante da elite imperial, dr. Francisco Furquim Werneck, em que a criança aparece já morta no colo sua mãe ${ }^{54}$. Sobre esse retrato a autora observa que, "com iluminação sombreada, fundo negro e efeito flou - todos os atributos visuais de constrição e retiro", ele é uma "imagem sensível que revela uma sensibilidade que foge às poses e trejeitos do retrato oitocentista" ${ }^{\prime 5}$. Com efeito, essas imagens testemunham uma nova sensibilidade: trata-se de celebrar e reverenciar, não mais o "anjinho", mas sim os valiosos sentimentos familiares, manifestados, nesse caso, na dor pela perda prematura do filho e expressos por meio de novos elementos antes ausentes do cerimonial fúnebre infantil. Daí a necessidade, conforme constatamos na fotografia e na passagem acima citada, de criar um clima de intimidade - fazendo alusão ao espaço familiar burguês - e, sobretudo, de gravidade, o que estabelece um contraste fundamental com os elementos de descontração e festividade que, como já se disse aqui, caracterizavam os funerais infantis.

Isso tudo reflete o que há de mais fundamental nas mudanças que ocorrem na sensibilidade e representações em relação à morte infantil ao longo do século XIX. Esse novo ambiente que se instala lao menos entre as elites urbanizadas) na segunda metade do século XIX e que resultou na emergência de uma prática e concepção de morte infantil, na qual a manifestação expansiva do pesar que esse acontecimento dava lugar começou a ser permitida, favorecida e mesmo valorizada, tem origem num movimento de valorização da família nuclear e dos sentimentos que a devem sustentar; e, ainda, de defesa de dois personagens do cenário doméstico: a mulher/mãe e a criança ${ }^{56}$. Inúmeros são os testemunhos desse processo no que se refere às mudanças relativas às representações da morte infantil. Ele aparece nas denúncias feitas aos índices de mortalidade infantil no país pelas autoridades médicas, que deixam de ver esse fenômeno como natural e passam a encará-lo como um crime contra a nação, que se priva de cidadãos úteis ${ }^{57}$. Reflete-se, igualmente, nas manifestações artísticas, em especial a poesia, que vai expor a tensão, cada vez maior, entre a representação de beleza da morte menina, a melhor das mortes - que, ao emoldurar uma vida que desconheceu a decadência e a corrupção, afigura-lhes como privilegiada -, e a exaltação da nobreza dos sentimentos daqueles que, com a morte prematura, vêem-se privados do objeto de seu amor; daí o luto materno como motivo que seria, mais de uma vez, utilizado. Por fim sabemos dessas mudanças através do que nos mostram os cemitérios. Em suas inúmeras esculturas e monumentos dedicados às crianças mortas, sempre ficam claros o sofrimento e o caráter trágico do evento, e eles tornam-se espaços por excelência da manifestação pública desses novos sentimentos. Em resumo, embora não cabendo afirmar que, de fato providencial, a morte infantil tenha passado à condição de fatalidade lastimada, é possível assinalar que, ao longo do século XIX, entre os segmentos mais urbanizados, a morte da criança torna-se um evento em que se passou a apreciar a expressão de uma série de sentimentos que, mesmo presentes, sua manifestação em público não era suficientemente legitimada nem apreciada. geral enterrados com o rosto descoberto. O dignatário e o homem rico são depositados num caixão fechado por um tampa de charneira; o citadino de medíocre fortuna é transportado em caixão sem tampa" (op. cit., p 211).A impressão de que, ao menos, nem todos são enterrados em caixões é reforçada pela descrição que Debret dá dos enterros de luxo entre as crianças escravas. Segundo ele, "exige locação temporária não somente da cadeirinha forrada de damasco mas ainda do pequeno caixão enfeitado com ramalhetes de flores artificiais e da coroa de fôlha fornecida pelo $a r$ mador. Terminado o entêrro todos os acessórios são devolvidos ao armador" (op. cit., p. 174).

43. LE GOFF, 1994,p. 446.

44. PERROT, 1991, p. 187191. Ver, em especial, p. 189.

45. Apud Le Goff (op.cit., p. 466).

46. Cf. Perrot (op. cit., p. 189).

47. MARTIN-FUGÏER, 1991, p. 195.

48. CORBIN, 1991,p. 426.

49. Segundo Corbin, "pela primeira vez a maior parte da população tem possibilidade de representar antepassados desaparecidos e parentes desconhecidos" (idem, ibidem)

50. Idem, ibidem

51. Cf. Keith McElroy (1987, p. 279).

52. MAUAD, 1997, p. 197.

53. Essa imagem encontra-se reproduzida em Lavelle (2003, p. 92). 
54. Cf. Mauad (1997, p. 222).

55. Idem, p. 228

56. Sobre isso ver Costa (1980), Rago (1997), Engel (1988)

57. Cf. Vailati (2005, p 212-222).
No que se refere às funções das fotografias dos membros familiares apontadas por Corbin, a imagem fotográfica da criança morta, ao servir de paliativo - tanto para sua ausência como, mais especificamente, para o problema de não ter podido ser fotografada em vida -, prestou-se, com efeito, a fornecer a representação imagética desta para a lembrança dos seus parentes próximos bem como para o conhecimento dos membros familiares espacial ou temporalmente distantes. Cumprindo essa exigência, a última imagem analisada, ao representar a gravidade e o luto da mãe, reforça ainda mais a vocação que os retratos de família têm para se assumirem como veículos da manifestação dos valores familiares. Esse incremento de importância, bem como o aumento da intensidade com a qual os indivíduos passam a vivenciar esses sentimentos, supõe a outra função da fotografia de que nos recorda Corbin, que é a de servir, por meio da posse da imagem, de alívio pela perda. Para nós, a importância dessa observação está no fato de a indagação - acerca da capacidade de as fotografias de crianças mortas cumprirem ou não essa função - permitir-nos pensar, além de outros significados que estiveram presentes nessa prática específica, acerca das razões da rapidez com que ela entrou em desuso, como também acerca dos possíveis motivos do estranhamento que hoje essa prática nos causa. A nosso ver, a resposta a essa questão é negativa: se, de alguma forma, a imagem do cadáver dá a conhecer algo do que este era quando vivo, ela não tem préstimo como substitutivo simbólico de sua presença efetiva, uma vez que, a todo o momento (por meio dos elementos que analisamos acima, como se não bastasse a mera presença do cadáver), está a lembrar a condição de morto do retratado. Isso certamente deve estar entre as razões da coincidência que existe entre uma crescente valorização da expressão dos sentimentos familiares - no nosso caso em particular, a de sofrimento diante da morte infantil - e o desaparecimento desse tipo de retrato, revelando que a antiga disposição emotiva que havia entre nossos antepassados para com essas imagens vai cedendo lugar a outras em que essas lembranças se tornam inaceitáveis e explica as reações que elas nos suscitam hoje, na medida em que a nossa sensibilidade deve ainda muito a essa transformação. Nesse sentido, cabe concluir que as fotografias de crianças mortas - a despeito de serem uma manifestação tardia (tendo em vista o período em estudo) das práticas que compunham o gestual fúnebre infantil, além do fato de serem boas sinalizadoras das mudanças em torno da criança morta - mostram (ao menos no caso da sociedade estudada, onde essa prática desapareceu) que estamos, sobretudo, diante de um uso "tradicional" de um instrumento novo. Este surge, não obstante, já associado a novos valores que, por serem incompatíveis com a representação ainda veiculada por esse uso específico, terminam, no caso em que os valores antigos vêm a prevalecer, como é o aqui apresentado, por determinar o fim dessa prática, que teve breve mas significativa vigência. Não é de espantar que a morte menina - na medida em que se torna, nos meios mais urbanizados, "a mais intolerável das mortes" - e o signo mais visível disto - o cadáver: a presença de uma ausência, como tanto já se observou - saiam com urgência de cena. 


\section{REFERÊNCIAS}

ARAÚJO,Alceu Maynard. Folclore Nacional III: Ritos, sabenças, linguagem, artes e técnicas. São Paulo: Melhoramentos, 1964.

CANDLER, John; BURGESS, Wilson. Narrative of a recent visit to Brasil. London: Edward Marsh, 1853.

CANSTAT, Oscar. Brasil. Terra e Gente.Trad. Eduardo de Lima e Castro. Rio de Janeiro: Conquista, 1975.

CHEVALIER, Jean; GHEERBRANT,Alain. Dicionário de Símbolos. Rio de Janeiro: José Olympio, 1995.

CORBIN,Alain. O segredo do indivíduo. In: PERROT, Michelle et al. História da Vida Privada, 4: da Revolução Francesa à Primeira Guerra. São Paulo: Companhia das Letras, 1991.p. 419-501.

COSTA, Jurandir Freire. Ordem médica e norma familiar. Rio de Janeiro: Graal, 1980.

DABADIE, F. A travers l'Amérique du Sud. Paris: Ferdinand Sartorius, 1858.

DEBRET, Jean-Baptiste. Viagem pitoresca e bistórica ao Brasil.Trad. e notas Sérgio Milliet. Belo Horizonte: Itatiaia; São Paulo: Edusp, 1989.

DELUMEAU, Jean. O que sobrou do paraíso? São Paulo: Companhia das Letras, 2003.

DENIS, Ferdinand. Brasil. Trad. João Etienne Filho e Malta Lima. Belo Horizonte: Itatiaia; São Paulo: Edusp, 1980.

ELIADE, Mircea (ed.). The Encyclopedia of Religion. New York: Macmillan, 1987.

ENGEL, Magali. Meretrizes e doutores: saber médico e prostituição no Rio de Janeiro (1840-1890). São Paulo: Brasiliense, 1988.

EWBANK,Thomas. A vida no Brasil: ou, Diário de uma visita à terra do cacaueiro e das palmeiras, com um apêndice contendo ilustrações das artes sul-americanas antigas. Trad. Jamil Almasur Haddad. Belo Horizonte: Itatiaia; São Paulo: Edusp, 1976.

FERGUSON, George Wells. Signs \& symbols in Christian art. New York: Oxford University Press, 1961.

JULIA, Dominique. L'enfance aux débuts de l'époque moderne. In: BECCHI, Egle;JULIA, Dominique (dir). Histoire de l'enfance en Occident. Tome 1. De l'Antiquité au XVIIe siècle. Paris: Éditions du Seuil, 1998. p. 286-373.

KIDDER, Daniel Parish. Reminiscências de viagens e permanência nas províncias do Sul do Brasil: Rio de Janeiro e São Paulo: compreendendo notícias históricas e geográficas do Império e 
das diversas províncias. Trad. Moacir N.Vasconcelos; not. biogr. Rubens Borba de Morais. Belo Horizonte: Itatiaia; São Paulo: Edusp , 1980.

LAVELLE, Patrícia. O espelbo distorcido: imagens do indivíduo no Brasil oitocentista. Belo Horizonte: Editora da UFMG, 2003.

LE GOFF, Jacques. História e Memória. Campinas: Editora da Unicamp, 1994.

LEMOS, Pe. Lourenço Borges de. Ritual do Arcebispado da Babia. Bahia:Typ. De Camillo de Lellis Marron \& Cia, 1863.

LUCCOCK, John. Notas sobre o Rio de Janeiro e partes meridionais do Brasil tomadas durante uma estada de dez anos nesse país de 1800 a 1818. Trad. Milton da Silva Rodrigues. São Paulo: Martins, 1942.

MARTIN-FUGÏER,Anne. Os ritos da vida privada burguesa. In: PERROT, Michelle et al. História da Vida Privada, 4: da Revolução Francesa à Primeira Guerra. São Paulo: Companhia das Letras, 1991. p. 193-261.

MAUAD, Ana Maria. Imagem e auto-imagem do Segundo Reinado. In:ALENCASTRO, Luiz Felipe (org.). História da Vida Privada no Brasil, 2: Império. São Paulo: Companhia das Letras, 1997. p. 181-232.

MAUAD, Ana Maria.A vida das crianças de elite durante o império. In: DEL PRIORE, Mary (org). História das crianças no Brasil. São Paulo: Contexto, 1999.

MCELROY, Keith. Death and photography in nineteenth century Peru. In: FUENTE, Beatriz de la (coord.).Arte funerario. Coloquio International de Historia del Arte. v. II. México, D. F.: Universidad Nacional Autónoma de México, 1987. p. 278-286.

PERROT, Michelle.A vida em família. In: PERROT, Michelle et al. História da Vida Privada, 4: da Revolução Francesa à Primeira Guerra. São Paulo: Companhia das Letras, 1991.p. 187-191.

PIKE, E. Royston. Diccionario de Religiones.Adap. Elsa Cecilia Frost. Mexico: Fondo de Cultura Económica, 1960.

RAGO, Margareth. Do cabaret ao lar: a utopia da cidade disciplinar: Brasil 1890-1830. São Paulo: Paz e Terra, 1997.

REIS, João José. A morte é uma festa: ritos fúnebres e revolta popular no Brasil do século XIX. São Paulo: Companhia das Letras, 1995.

RODRIGUES, Cláudia. Lugares dos mortos na cidade dos vivos: tradições e transformações fúnebres no Rio de Janeiro. Rio de Janeiro: Secretaria Municipal de Cultura, 1997.

SIEDLER, Carl. Dez anos no Brasil. Trad. Bertholdo Klinger. Belo Horizonte: Itatiaia; São Paulo: Edusp, 1980. 
STEWART, Charles Samuel. A visit to the South Seas in the U.S. Ship Vicennes, during the years 1829 and 1830; with notices of Brasil, Peru, Manulla, the Cape of Good Hope, and St. Helena. London: Fisher, Son, \& Jackson, 1832.

VAILATI, Luiz Lima. A morte menina: práticas e representações da morte infantil no Brasil dos oitocentos (Rio de Janeiro e São Paulo). 2005. Tese (Doutorado em em História Social) - Faculdade de Filosofia Letras e Ciências Humanas, Universidade de São Paulo, São Paulo, 2005.

VENÂNCIO, Renato Pinto. Maternidade Negada. In: DEL PRIORE, Mary. Historia das mulheres no Brasil. São Paulo: Contexto, 1997.p. 189-222.

WETHERELL, James. Brazil. Stray notes from Bahia being extracts from letters, \&c., during a residence of fifteen years.Liverpool:Webb and Hunt, 1860.

Artigo apresentado em 9/2006. Aprovado em 11 1/2006. 